\title{
Expression of adrenergic receptors in mouse preimplantation embryos and ovulated oocytes
}

\author{
Štefan Čikoš, Pavol Rehák, Soňa Czikková, Jarmila Veselá and Juraj Koppel \\ Institute of Animal Physiology, Slovak Academy of Sciences, Šoltésovej 4, 04001 Košice, Slovakia \\ Correspondence should be addressed to ̌̌ Čikoš; Email: cikos@saske.sk
}

\begin{abstract}
Epinephrine and norepinephrine can play an important role in basic developmental processes such as embryogenesis and morphogenesis, regulating cell proliferation, differentiation and migration. We showed that $\beta$-adrenergic receptors can mediate the effects of catecholamines on preimplantation embryos in our previous work. In the present study, we designed specific oligonucleotide primers which can distinguish among all members of the $\alpha$-adrenergic receptor family, and showed (using RT-PCR) that the $\alpha 2 \mathrm{C}$-adrenergic receptor is transcribed in ovulated oocytes, 8- to 16-cell morulae and expanded blastocysts. We did not detect the $\alpha 2 \mathrm{C}$-adrenoceptor transcript in 4-cell embryos. Our immunohistochemical study showed the presence of $\alpha$-2Cadrenoceptor protein in ovulated oocytes, 8- to 16- cell embryos and blastocysts, but the signal in 4-cell embryos was weak, and probably represents remaining protein of maternal origin. We did not detect any other $\alpha$-adrenergic receptor in preimplantation embryos and oocytes. Exposure of mouse preimplantation embryos to the $\alpha 2$-adrenergic agonist UK 14304 led to significant reduction of the embryo cell number, and the effect was dose dependent. Our results suggest that epinephrine and norepinephrine could affect the embryo development in the oviduct via adrenergic receptors directly and support the opinion that maternal stress can influence the embryo even in very early pregnancy.
\end{abstract}

Reproduction (2007) 133 1139-1147

\section{Introduction}

Epinephrine and norepinephrine are well-known neurotransmitters and hormones that play an essential role in the regulation of the cardiovascular system and energy metabolism, especially in the case of stress or increased energy need. In addition to these well-known effects, epinephrine and norepinephrine can also play an important role in basic developmental processes such as embryogenesis and morphogenesis, regulating cell proliferation, differentiation, and migration (for review, see Buznikov et al. 1996, Pendleton et al. 1998, Weiss et al. 1998, Herlenius \& Lagercrantz 2001). The essential role of epinephrine and norepinephrine in mouse fetal development has been clearly demonstrated, when mice lacking the capability to synthesize these compounds died in utero or shortly after birth (Kobayashi et al. 1995, Thomas et al. 1995, Zhou et al. 1995).

In our previous work, we demonstrated the possibility of direct influence of epinephrine and norepinephrine on the very early embryo (before its implantation into the uterus) via three subtypes of $\beta$-adrenergic receptors (Čikoš et al. 2005). The $\beta$-adrenoceptors belong, together with $\alpha 1$ - and $\alpha 2$ - adrenoceptors, to the adrenergic receptor family of $\mathrm{G}$ protein-coupled receptors. To transduce extracellular signals, the receptors couple to heterotrimeric GTP-binding $(\mathrm{G})$ proteins which activate various effectors. The $\beta$-adrenoceptors couple predominantly to $G$ s proteins ( $G$ proteins which stimulate adenylyl cyclase activity), $\alpha 1$-adrenoceptors couple predominantly to $\mathrm{Gq}$ proteins $(\mathrm{G}$ proteins which stimulate phospholipase $\mathrm{C}$ activity) and $\alpha 2$-adrenoceptors couple predominantly to $\mathrm{Gi}$ proteins (G proteins which inhibit adenylyl cyclase activity). Signaling pathways leading from adrenergic receptors then regulate the activity of metabolic enzymes, ion channels or transcription factors (for review see, Watson \& Arkinstall 1994, Saunders \& Limbird 1999). Moreover, the adrenergic receptors can activate mitogen-activated protein kinases and thereby influence fundamental cellular processes (Alblas et al. 1993, DeGraff et al. 1999, Schramm \& Limbird 1999, Kim et al. 2002, Shizukuda \& Buttrick 2002, Pullar \& Isseroff 2003).

To ascertain whether epinephrine and norepinephrine could influence the preimplantation embryo also via $\alpha$-adrenergic receptors, in the present study we examined the expression of all subtypes of $\alpha 1$ - and $\alpha 2$ - adrenergic receptors in mouse embryos at various stages of preimplantation development. 


\section{Materials and Methods}

\section{Informatics analysis and primer design}

Nucleotide sequences of mouse adrenergic receptors were obtained from public databases (GenBank, available at http://www.ncbi.nlm.nih.gov/ and GPCRDB: Information system for G protein-coupled receptors, available at http://www.gpcr.org/7tm/). MRNA nucleotide sequences of $\alpha 1 \mathrm{~A}_{-}, \alpha 1 \mathrm{~B}_{-}, \alpha 1 \mathrm{D}_{-}, \alpha 2 \mathrm{~A}-, \alpha 2 \mathrm{~B}-$, and $\alpha 2 \mathrm{C}$ - adrenergic receptors (GenBank accesion numbers: AF031431, XM _126326, S80044, M99377, M94583, M97516) were aligned using Clustal W (Higgins et al. 1996) and Blast 2 algorithms (Altschul et al. 1997). The regions which do not exert significant nucleotide homology among the members of the $\alpha$-adrenergic receptor family were selected for location of primers. The primers were designed using the program Primer 3 (available at http://biotools.umassmed.edu/ bioapps/primer3_www.cgi) and analysis of appropriate PCR products for recognition sites of restriction enzymes was performed using the program Webcutter 2.0 (available at http://rna.lundberg.gu.se/cutter2/).

\section{Embryo recovery}

All animal experiments were approved by the Ethical Committee of the Institute of Animal Physiology SAS, Košice. Female mice (ICR strain, Velaz, Prague, Czech Republic; 4-5 weeks old) underwent superovulation treatment by i.p. injection of $5 \mathrm{IU}$ of serum gonadotropin (Folligon, Intervet International Bv. Boxmeer, Holland), followed $46 \mathrm{~h}$ later by administration of $5 \mathrm{IU}$ of human chorionic gonadotropin (hCG, Organon, Oss, Holland). The mice were killed by cervical dislocation $24 \mathrm{~h}$ after hCG and unfertilized oocytes (at metaphase II) were isolated by flushing from the oviduct. To obtain preimplantation embryos, females were mated with males of the same strain overnight (mating was confirmed by identification of a vaginal plug), killed by cervical dislocation (57-, 72-, or $98 \mathrm{~h}$ after hCG) and the embryos (4-cell embryos, 8-16-cell morulae and expanded blastocysts) were isolated by flushing from the oviduct or uterus. Oocytes and embryos were washed in several drops of flushing-holding (FHM) medium (Lawits \& Biggers 1993) containing $1 \%$ BSA and pooled according to their morphology. Cumulus cells were removed with $0.1 \%$ hyaluronidase (Sevac, Prague, Czech Republic).

\section{RT-PCR}

Total RNA was extracted from batches of 100-150 mouse preimplantation embryos and unfertilized oocytes. The RNA was also isolated from mouse tissues known to be rich in $\alpha$-adrenergic receptors (brain, heart and liver), which served as positive controls. TRIzol Reagent (Invitrogen Life technologies) was used according to the manufacturer's instructions. Contaminating DNA in RNA preparations was digested by incubation for $15 \mathrm{~min}$ at $22{ }^{\circ} \mathrm{C}$ with amplification grade DNase I (Invitrogen Life technologies) in $20 \mathrm{mM}$ Tris- $\mathrm{HCl} \mathrm{pH} \mathrm{8.4,} 2 \mathrm{mMMgCl}_{2}$ and $50 \mathrm{mM} \mathrm{KCl}$. The DNase I reaction was stopped by ethanol precipitation. RNA pellets were dissolved in water and denatured by incubation for $15 \mathrm{~min}$ at $65^{\circ} \mathrm{C}$.

The RNA was reverse transcribed at $42^{\circ} \mathrm{C}$ for $1 \mathrm{~h}$ in $20 \mu \mathrm{l}$ containing 200 units of Superscript II RNase $\mathrm{H}^{-}$Reverse Transcriptase (Invitrogen Life technologies), $4 \mu \mathrm{M}$ oligo dT18, $50 \mathrm{mM}$ Tris-HCl pH 8.3, $3 \mathrm{mM} \mathrm{MgCl}$, $75 \mathrm{mM} \mathrm{KCl,}$ $10 \mathrm{mM}$ DTT, $500 \mu \mathrm{M}$ dNTPs (dATP, dTTP, dCTP, dGTP), 40 units RNase OUT (Recombinant RNase Inhibitor, Invitrogen Life technologies) and $0.5 \mu \mathrm{g}$ acetylated BSA. The reaction was terminated by heating at $95^{\circ} \mathrm{C}$ for $5 \mathrm{~min}$. To check for the presence of genomic DNA contamination in the RNA preparations, reverse transcriptase negative controls (no reverse transcriptase in the reaction) were carried out in parallel, using half from each RNA sample. The cDNA preparations were then cleaned by ethanol precipitation (Liss 2002) and the cDNA pellets were diluted in an appropriate amount of $10 \mathrm{mM}$ Tris ( $\mathrm{pH} 8.3$ ) so that $1 \mu$ of the cDNA corresponded to 2.5 embryo/oocyte equivalents.

PCR amplification was carried out in the presence of $0.5 \mu \mathrm{M}$ of each oligonucleotide primer (see Table 1), $50 \mathrm{mM}$ $\mathrm{KCl}, 10 \mathrm{mM}$ Tris- $\mathrm{HCl} \mathrm{pH} \mathrm{8.3,2} \mathrm{mM} \mathrm{MgCl} 2,0.2 \mathrm{mMdNTPs}$ (dATP, dTTP, dCTP, dGTP), and 0.05 units/ $\mu$ Taq DNA polymerase (Invitrogen Life Technologies). One microliter of CDNA was amplified in $25 \mu \mathrm{l}$ PCR mix. For $\alpha 1 \mathrm{~B}-, 1 \mathrm{D}-$, $2 \mathrm{~A}-$, and 2B- adrenoceptors, an initial denaturation step at $95^{\circ} \mathrm{C}$ for 2 min was followed by 40 cycles at $94{ }^{\circ} \mathrm{C}$ for $30 \mathrm{~s}$ and $68{ }^{\circ} \mathrm{C}$ for $90 \mathrm{~s}$. For $\alpha 1 \mathrm{~A}$-, and $2 \mathrm{C}$ - adrenoceptors an initial denaturation step at $95^{\circ} \mathrm{C}$ for 2 min was followed by 40 cycles at $94{ }^{\circ} \mathrm{C}$ for $30 \mathrm{~s}, 63{ }^{\circ} \mathrm{C}$ for $45 \mathrm{~s}$, and $72{ }^{\circ} \mathrm{C}$ for $45 \mathrm{~s}$. To check for the presence of cross contamination, the reaction with water instead of cDNA was performed concurrently (blank reaction). Detection of $\beta$-actin transcript using $\beta$-actin primers (5'-GTGGGCCGCTCTAGGCACCAA-3' and 5'-CTCTTTGATGTCACGCACGATTTC- $3^{\prime}$, give a 539 bp PCR product; Temeles et al. 1994) served as a control for RNA integrity and the RT-PCR process.

The PCR products were analyzed using electrophoresis on a $\%$ agarose gel stained with SYBR Green I (Sigma). A 100 bp DNA ladder and a 25 bp DNA ladder (Invitrogen Life technologies) were used as markers to determine the size of the PCR products. To confirm the amplification of the correct sequences, we digested the obtained PCR products with appropriate restriction enzymes - amplification reactions were ethanol precipitated, and DNA pellets were dissolved in TE buffer (10mM Tris, $1 \mathrm{mM}$ EDTA, $\mathrm{pH}$ 8.0) and digested with the restriction enzyme in the appropriate reaction buffer.

\section{Immunostaining}

Preimplantation embryos and oocytes were isolated as described above and the zona pellucida was removed with $0.5 \%$ pronase in $\mathrm{KSOM}$ at $37^{\circ} \mathrm{C}$. Zona-free oocytes 
Table 1 Primer sequences and locations on gene, predicted size of amplicons.

\begin{tabular}{|c|c|c|c|}
\hline Gene & Primer sequence $\left(5^{\prime}-3^{\prime}\right)$ & $\begin{array}{l}\text { Primer } \\
\text { location }\end{array}$ & $\begin{array}{c}\text { Amplicon } \\
\text { size (bp) }\end{array}$ \\
\hline \multirow[t]{2}{*}{$\alpha 1 \mathrm{~A}$} & FP: CAGATGGAGTCTGTGAATGGAA & $\begin{array}{l}\mathrm{COOH}, \\
\text { exon } 2\end{array}$ & 185 \\
\hline & RP: AATGGTTGGAACTTGGTGATTT & $\begin{array}{c}\mathrm{COOH}, \\
\text { exon } 2\end{array}$ & \\
\hline \multirow[t]{2}{*}{$\alpha 1 B$} & FP: ATACCTGGGTCGTGGAACG & $\begin{array}{l}\mathrm{COOH}, \\
\text { exon } 2\end{array}$ & 140 \\
\hline & RP: GGAGCTTGAAAGTGAAGAGTGG & $\begin{array}{c}\mathrm{COOH}, \\
\text { exon } 2\end{array}$ & \\
\hline \multirow[t]{2}{*}{$\alpha 1 D$} & FP: AGCACTACGCGCAGCCTC & $\begin{array}{l}3 \mathrm{CL} \text {, } \\
\text { exon } 1\end{array}$ & 127 \\
\hline & RP: TGCTACTCTGTGTCCCTGGATT & $\begin{array}{l}3 \mathrm{CL} \\
\text { exon } 1\end{array}$ & \\
\hline \multirow[t]{2}{*}{$\alpha 2 A$} & FP: TTCTTTTTTCACCTACACGCTCA & $6 \mathrm{TM}$ & \\
\hline & RP: TGTAGATAACAGGGTTCAGCGA & $7 \mathrm{TM}$ & 112 \\
\hline \multirow[t]{2}{*}{$\alpha 2 B$} & FP: ACCTTCCCTTGCTGACTGTACT & $3^{\prime}$ UTR & 112 \\
\hline & RP: TGGGAGGGAGGTATTCTAATCA & $3^{\prime}$ UTR & \\
\hline \multirow[t]{2}{*}{$\alpha 2 C$} & FP: GGCTGTGAACTTAGGGCTTTAG & $3^{\prime}$ UTR & 105 \\
\hline & RP: ATAGGAAGTCAGCCCTTGCTC & $3^{\prime}$ UTR & \\
\hline
\end{tabular}

$\mathrm{FP}$, forward primer; $\mathrm{RP}$, reverse primer; $\mathrm{COOH}$, a sequence coding receptor carboxy-terminus; $3 \mathrm{CL}$, a sequence coding potential $3 \mathrm{rd}$ cytoplasmic loop; 6 TM, a sequence coding potential 6th transmembrane region; $7 \mathrm{TM}$, a sequence coding potential 7 th transmembrane region; $3^{\prime} \cup T R$, untranslated sequence at the $3^{\prime}$ end of mRNA; bp, base pairs.

and embryos were washed thrice in PBS/BSA (PBS containing BSA; Sigma-Aldrich), fixed in methanol at $10{ }^{\circ} \mathrm{C}$ (Sigma-Aldrich) for $5 \mathrm{~min}$, then washed in $\mathrm{PBS} / \mathrm{BSA}$, followed by washing in PBS/BSA/SAP (PBS/BSA containing $0.05 \%$ saponin (SAP); Sigma-Aldrich). Nonspecific immunoreactions were blocked with $2.25 \%$ normal donkey serum (Santa Cruz Biotechnology, Santa Cruz, CA, USA) and $0.1 \%$ saponin in PBS for $45 \mathrm{~min}$ at room temperature. The oocytes and embryos were incubated with the primary antibody raised against the a2C-adrenergic receptor (affinity-purified goat polyclonal antibody, $\alpha 2 C-A R$ C-20, Santa Cruz Biotechnology, $2 \mu \mathrm{g} / \mathrm{ml}$ ) in PBS/BSA/SAP at $4{ }^{\circ} \mathrm{C}$ overnight. After extensive washing in PBS/BSA/SAP, specific secondary antibody coupled with fluorescein (donkey anti-goat IgG-FITC, Santa Cruz Biotechnology, $2 \mu \mathrm{g} / \mathrm{ml}$ ) was used to visualize primary antibody reactions $(30 \mathrm{~min}$ at room temperature). Afterwards, oocytes and embryos were washed in PBS/BSA/SAP and PBS/BSA, mounted on glass slides in UltraCruz mounting medium (Santa Cruz Biotechnology, contains DAPI for cell nuclei staining), sealed with coverslips and observed using an epifluorescent microscope (BX 51 Olympus, Tokyo, Japan).

Negative control groups of oocytes and embryos were incubated without the primary antibody or without the primary and secondary antibody, or with the primary antibody preadsorbed with an excess (20 times by weight) of the immunizing peptide according to the manufacturer's protocol (Blocking peptide, a2C-AR C20 P, Santa Cruz Biotechnology). Oocytes and embryos in each experimental group (incubation with primary antibody) were evaluated by comparison with control groups of oocytes and embryos.

\section{Embryo culture and morphological evaluation}

The four-cell embryos were isolated by flushing from the oviduct in FHM medium $57 \mathrm{~h}$ after hCG. They were washed thrice in KSOM culture medium, transferred into $30 \mu \mathrm{l}$ drops of KSOM media supplemented with UK 14304 (Sigma-Aldrich) dissolved in DMSO or with the equivalent volume of DMSO alone and cultured in a humidified atmosphere with $5.0 \% \mathrm{CO}_{2}$ at $37^{\circ} \mathrm{C}$ for $60 \mathrm{~h}$. Three doses of UK 14304 were used: UK 14304 was dissolved in DMSO and added to a KSOM culture medium (Lawits \& Biggers 1993) at final concentrations of $0.1,1$, and $10 \mu \mathrm{M}$ at the beginning of the incubation period and then 20 and $40 \mathrm{~h}$ later. The control groups of embryos were cultured in the presence of the equivalent amounts of solvent (DMSO) added into the KSOM at the same time as UK 14304 (the compounds were added in the volume of $1 \mu \mathrm{l}$ ).

After the $60 \mathrm{~h}$ of incubation, the embryos were stained with Hoechst $33342(20 \mu \mathrm{g} / \mathrm{ml}$; Sigma-Aldrich) for $10 \mathrm{~min}$ at $37^{\circ} \mathrm{C}$, washed, sealed with coverslips, and observed using an epifluorescent microscope (BX 51 Olympus). The number of cell nuclei was determined in all embryos. Each embryo was assigned to one of the four classes according to the cell number (developmental stage). Following classes were established: embryos with cell number less than 16, embryos with cell number between 17 and 32, embryos with cell number between 33 and 64, and embryos with cell number 65 and more. The distribution of embryos among the four developmental classes was then analyzed.

To eliminate experimental bias, at least three independent series were performed in each experimental group (the three UK 14304 doses and the control group) and the results were pooled. The following total numbers of embryos ( $n$ ) were examined: $10 \mu \mathrm{M}$ UK 14304 $n=139 ; 1 \mu \mathrm{M}$ UK $14304 n=113 ; 0.1 \mu \mathrm{M}$ UK 14304 $n=140$; DMSO controls $n=148$.

The One-way ANOVA followed by Duncan's test was used for evaluating the embryo cell number, while the chisquared test was used for analyzing embryo distribution. Differences of $P \leq 0.05$ were considered significant.

\section{Results \\ Primer design}

We located the primers for $\alpha$-adrenergic receptors mainly in regions encoding a portion of the receptor outside of transmembrane domains, which are less conserved than transmembrane domains. The primers for $\alpha 1 \mathrm{D}$-adrenoceptor also detect an alternative splice variant coding longer adrenoceptor isoform (GenBank accession number XM_141369). The primers for $\alpha 1 \mathrm{~A}$ adrenoceptor do not detect two potential alternative 
transcripts lacking a part of the coding sequence from the second exon (GenBank unfinished high-throughput cDNA sequences AK085653 and AK042759, lastly modified in October 2006). Sequences and locations of the primers are shown in Table 1.

Amplification reaction for each primer pair was optimalized using positive controls - mouse tissues known to be rich in the receptor (Fig. 1a). The identity of each PCR product was verified by digestion with appropriate restriction enzymes according to the sequence information: digestion of the $\alpha 1 \mathrm{~A}$-adrenoceptor PCR product (185 bp) with Alu I gave 112 and $73 \mathrm{bp}$ DNA fragments, digestion of the $\alpha 1 \mathrm{~B}$-adrenoceptor PCR product (140 bp) with Alu I gave 102 and 34 bp DNA fragments (the remaining 4 bp DNA fragment is not detectable on $2 \%$ agarose gel), digestion of the $\alpha 1 \mathrm{D}$ adrenoceptor PCR product (127 bp) with Hpa II gave 87 and $40 \mathrm{bp}$ DNA fragments, digestion of the a2A-adrenoceptor PCR product (112 bp) with Hpa II gave 73 and 39 bp DNA fragments, digestion of the $\alpha 2 \mathrm{~B}-$ adrenoceptor PCR product (112 bp) with Taq I gave 74 and $38 \mathrm{bp}$ DNA fragments, digestion of the $\alpha 2 \mathrm{C}$ adrenoceptor PCR product (105 bp) with Alu I gave 81 and $24 \mathrm{bp}$ DNA fragments, and digestion with Mbo II gave 67 and 38 bp DNA fragments (Fig. 2).

\section{Expression of $\alpha$-adrenergic receptor $m R N A s$}

Mouse oocytes and preimplantation embryos at various developmental stages (four-cell embryos, 8- to 16-cell

(a)

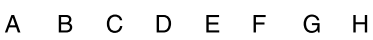

$100 \mathrm{bp}$ $200 \mathrm{bp}$

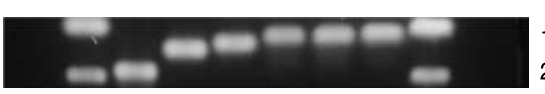

$100 \mathrm{bp}$ $200 \mathrm{bp}$

(b)

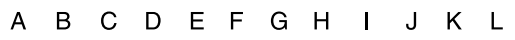

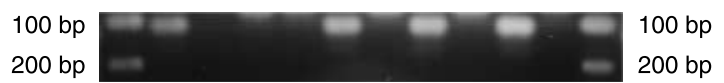

Figure 1 RT-PCR with primers for $\alpha$-adrenergic receptors. (a) RT-PCR with primers for $\alpha$-adrenergic receptors in mouse positive control tissues. Agarose gels with separated PCR products are shown. Primers detecting $\alpha 1 \mathrm{~A}$ - (lane $\mathrm{B}$, the $185 \mathrm{bp}$ PCR product) and $\alpha 1 \mathrm{~B}$ - (lane $\mathrm{C}$, the 140 bp PCR product) adrenoceptors were used with heart cDNA, primers detecting $\alpha 1 \mathrm{D}$ - (lane $\mathrm{D}$, the $127 \mathrm{bp}$ PCR product), $\alpha 2 \mathrm{~A}$ - (lane $\mathrm{E}$, the 112 bp PCR product), and $\alpha 2 \mathrm{C}$ - (lane $\mathrm{G}$, the $105 \mathrm{bp}$ PCR product) adrenoceptors were used with brain CDNA, primers detecting $\alpha 2 \mathrm{~B}$ adrenoceptor (lane $F$, the $112 \mathrm{bp}$ PCR product) were used with liver cDNA. Lanes $\mathrm{A}$ and $\mathrm{H}$, molecular weight markers (MWM). The sizes of the MWM in base pairs (bp) are indicated to the left and the right of the panel respectively. (b) RT-PCR analysis of $\alpha 2 \mathrm{C}$-adrenoceptor mRNA expression in mouse oocytes and preimplantation embryos. Agarose gels with separated PCR products (the 105 bp PCR product corresponds to the $\alpha 2 \mathrm{C}$-adrenoceptor) are shown. Lanes: $\mathrm{B}$, oocytes; $\mathrm{D}$, four-cell embryos; F, 8- to 16- cell embryos; $\mathrm{H}$, blastocysts; J, positive control tissue (brain); C, E, G and I, corresponding reverse transcriptase negative controls; $\mathrm{K}$, blank reaction. Lanes $\mathrm{A}$ and $\mathrm{L}$, molecular weight markers (MWM). The sizes of the MWM in base pairs (bp) are indicated to the left and the right of the panel respectively. morulae and expanded blastocysts) were examined by RT-PCR using reaction conditions which were optimalized for each primer pair in the positive control tissues before examination. An amount of cDNA corresponding to 2.5 embryo/oocyte equivalents was amplified in 40 cycles and analyzed on agarose gel.

We detected a PCR product corresponding to the $\alpha 2 \mathrm{C}$ adrenergic receptor (105 bp) in oocytes, 8- to 16-cell morulae, and expanded blastocysts. No PCR product was detected in four-cell embryos or in the reactions where reverse transcriptase or cDNA were omitted (Fig. 1b). Digestion of the $105 \mathrm{bp}$ PCR product with appropriate restriction enzymes produced DNA fragments of the expected sizes: digestion with Alu I gave 81 and 24 bp DNA fragments and digestion with Mbo II gave 67 and 38 bp DNA fragments (Fig. 2).

PCR products corresponding to other $\alpha$-adrenergic receptor mRNAs were not detected in the oocytes and embryos, even after an increase of cDNA amount in PCR or after an additional 25 cycles of reamplification (data not shown).

The embryos produced a PCR fragment corresponding to the $\beta$-actin mRNA at all developmental stages, thus confirming the integrity of the RNA and the RT-PCR process (data not shown).

\section{Immunohistochemical study}

The immunoreactive $\alpha 2 \mathrm{C}$-adrenergic receptor was identified in oocytes, 8- to 16-cell morulae, and blastocysts, but the signal was weak in four-cell embryos (Fig. 3). The specificity of the signal was confirmed using several controls: the immunostaining intensity was significantly reduced in controls incubated with the primary antibody preadsorbed with the immunizing peptide (Fig. 3) or in controls incubated without the

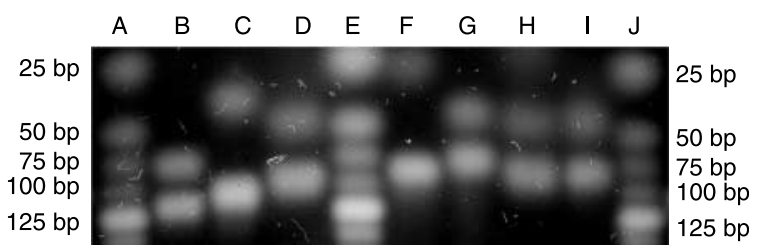

Figure 2 Digestion of the PCR products with restriction enzymes. Lanes: $\mathrm{B}$, digestion of the $\alpha 1 \mathrm{~A}$-adrenoceptor PCR product with Alu I (112+ 73 bp DNA fragments); C, digestion of the $\alpha 1 \mathrm{~B}$-adrenoceptor PCR product with Alu I (102+34 bp DNA fragments); D, digestion of the a1D-adrenoceptor PCR product with Hpa II $(87+40$ bp DNA fragments); F, digestion of the $\alpha 2 \mathrm{C}$-adrenoceptor $\mathrm{PCR}$ product with Alu I $(81+24$ bp DNA fragments); G, digestion of the $\alpha 2 \mathrm{C}$-adrenoceptor PCR product with Mbo II $(67+38$ bp DNA fragments); $\mathrm{H}$, digestion of the $\alpha 2 \mathrm{~A}$-adrenoceptor PCR product with Hpa II $(73+39$ bp DNA fragments); I, digestion of the $\alpha 2 \mathrm{~B}$-adrenoceptor PCR product with Taq I (74+38 bp DNA fragments). Lanes A, E, and J, molecular weight markers (MWM). The sizes of the MWM in base pairs (bp) are indicated to the left and the right of the panel respectively. 
primary antibody or without the primary and secondary antibody (data not shown).

\section{Effect of UK 14304 on embryo development}

Table 2 shows the analysis of embryo distribution after incubation of the mouse preimplantation embryos with different doses of the $\alpha 2$-adrenoceptor agonist UK 14 304. Highly significant changes $(P<0.001)$ in embryo distribution with an increased proportion of embryos with lower cell numbers and decreased proportion of embryos with higher cell numbers were found after the UK 14304 treatment. Incubation of the embryos with UK 14304 led to significant reduction of the mean embryo cell number in comparison with the control embryos and the response was dose dependent (Fig. 4).

\section{Discussion}

We showed that $\beta$-adrenergic receptors are expressed in mouse oocytes and preimplantation embryos in our previous work (Čikoš et al. 2005). To extend our knowledge to all members of the adrenergic receptor family, we proceeded to examine the expression of $\alpha$-adrenergic receptors in mouse preimplantation embryos and oocytes. We detected the a2C-adrenoceptor transcript in oocytes, 8- to 16- cell embryos, and blastocysts, but not in four-cell embryos. These results suggest that ovulated oocytes express the $\alpha 2 \mathrm{C}$-adrenoceptor and that transcription of the embryonal $\alpha 2 \mathrm{C}$-adrenoceptor gene begins around the 8- to 16cell stage. In accordance with the results of the RT-PCR experiment, our immunohistochemical study showed
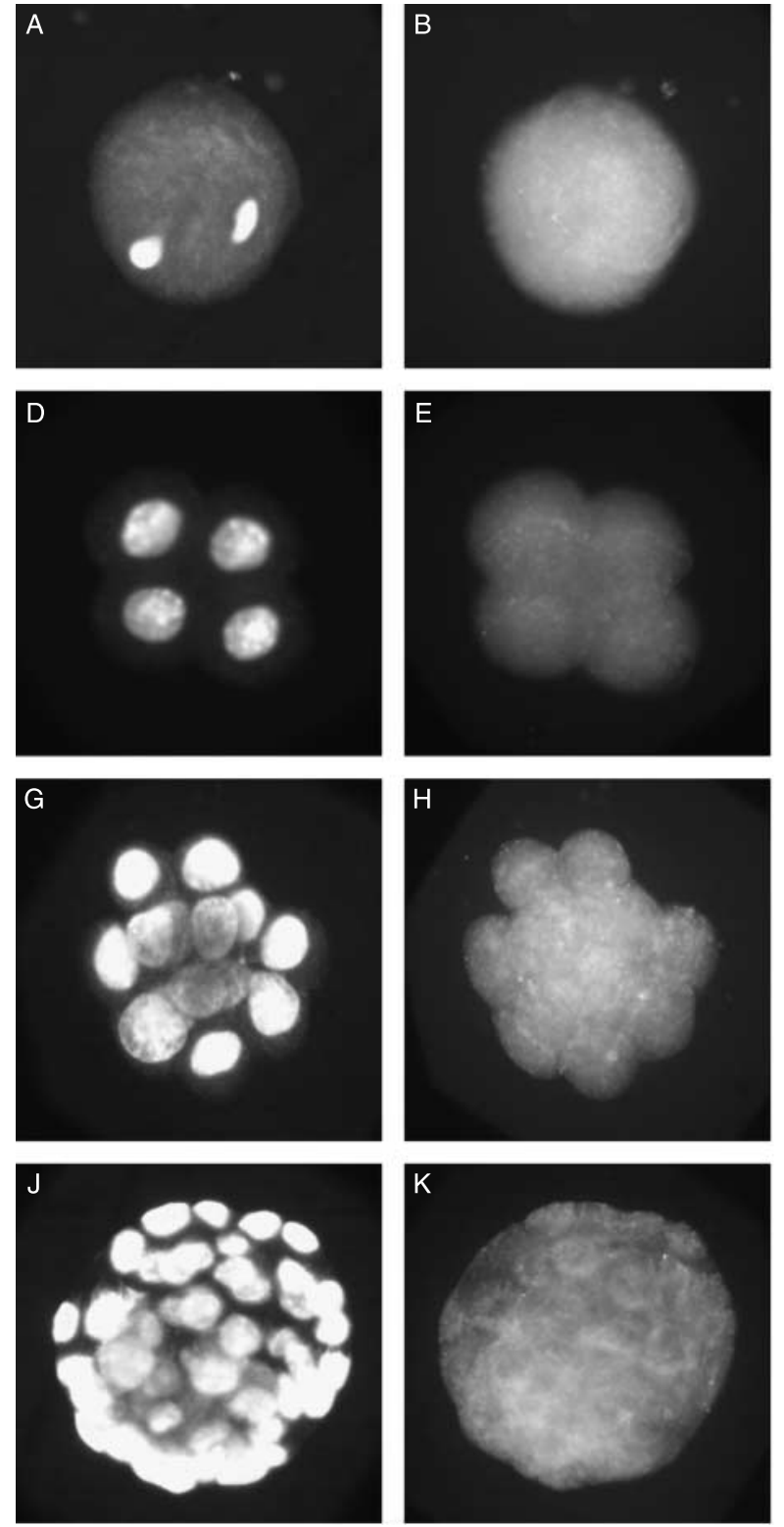
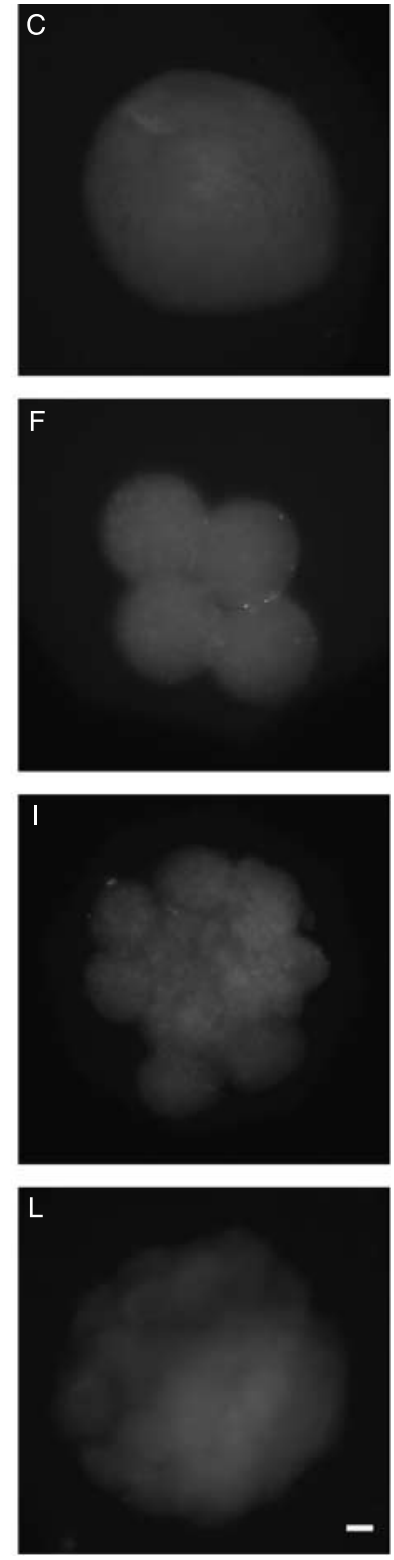

Figure 3 Immmunohistochemical localization of the $\alpha 2 \mathrm{C}$-adrenoceptor in mouse oocytes (A, B and C), four-cell embryos (D, $\mathrm{E}$ and $\mathrm{F}$ ), 8- to 16-cell embryos (G, $\mathrm{H}$ and I), and blastocysts (J, K and L). Representative images are shown. A, D, G and J: Cell nuclei stained with DAPI; B, E, H and $\mathrm{K}$ : Oocytes/embryos incubated with the antibody against the $\alpha 2 \mathrm{C}$-adrenoceptor (identical samples as in images A, D, G and J); C, F, I and L: Oocytes/embryos incubated with the antibody against the $\alpha 2$-adrenoceptor preadsorbed with the immunizing peptide. The bar, $10 \mu \mathrm{m}$. 
Table 2 Embryo distribution after incubation of mouse embryos with UK 14304.

\begin{tabular}{lcccc}
\hline $\begin{array}{l}\text { Embryo cell } \\
\text { number }\end{array}$ & Control & UK $0.1 \mu \mathrm{M}$ & UK $1.0 \mu \mathrm{M}$ & UK $10.0 \mu \mathrm{M}$ \\
\hline$<16$ cells $^{\mathrm{a}}$ & 10.1 & 24.3 & 25.7 & 30.9 \\
$17-32$ cells $^{\mathrm{a}}$ & 17.6 & 17.2 & 18.6 & 27.3 \\
$33-64$ cells $^{\mathrm{a}}$ & 41.9 & 46.4 & 46.9 & 35.3 \\
$>^{265 \text { cells }^{\mathrm{a}}}$ & 30.4 & $12.1^{* \mathrm{~b}}$ & $8.8^{* \mathrm{~b}}$ & $6.5^{* \mathrm{~b}}$ \\
$\begin{array}{l}\text { Number of } \\
\text { embryos }\end{array}$ & 148 & 140 & 113 & 139 \\
\hline
\end{tabular}

The four-cell mouse embryos were incubated in the presence of indicated concentrations of UK 14304 (UK) for $60 \mathrm{~h}$. Each embryo was then assigned to one of the four classes according to the cell number $(<$ 16 cells, 17-32 cells, 33-64 cells, $>65$ cells) and the distribution of embryos among the four developmental classes was analyzed.

${ }^{a}$ The number of embryos from each experimental group (Control, UK 0.1 , UK 1.0, UK $10.0 \mu \mathrm{M}$ ) belonging to the indicated developmental classes is expressed as a percentage. ${ }^{b}$ Statistical difference between the control group and UK 14304 treated groups: ${ }^{*} P<0.001$.

the presence of $\alpha 2 \mathrm{C}$-adrenoceptor protein in ovulated oocytes, 8- to 16- cell embryos, and blastocysts, but the signal in four-cell embryos was weak and probably represents the remaining protein of maternal origin. We did not detect any other $\boldsymbol{\alpha}$-adrenergic receptor in preimplantation embryos and oocytes.

Taken together, the results of our previous work (Čikoš et al. 2005) and the results of the present study indicate that two types of adrenergic receptors are expressed in mouse ovulated oocytes and preimplantation embryos. The receptors are under the control of the same natural ligands (epinephrine, norepinephrine) but they couple primarily to $G$ proteins with opposing actions on adenylyl cyclase activity ( $\beta$-adrenoceptors to Gs, $\alpha 2-$ adrenoceptors to $\mathrm{Gi}$ ). Co-stimulation of the two receptors in the same cell might be expected to

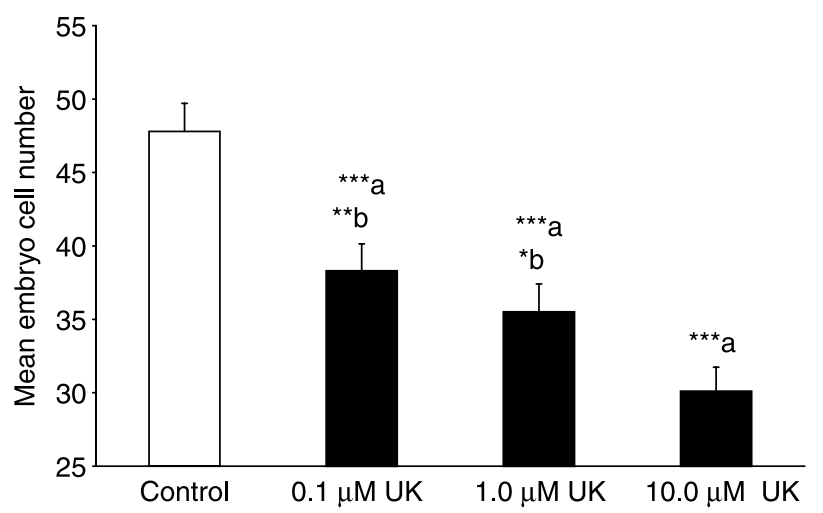

Figure 4 Embryo cell number after incubation with UK 14 304. The four-cell mouse embryos were incubated in the presence of indicated concentrations of UK 14304 (UK) for $60 \mathrm{~h}$ and then the cell number was estimated. Values are arithmetical means +S.E.M. Numbers of embryos (n): $10 \mu \mathrm{M}$ UK $14304 n=139 ; 1.0 \mu \mathrm{M}$ UK $14304 n=113$;

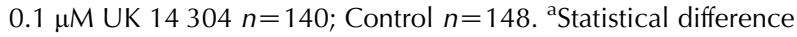
between the control group of embryos and the UK 14 304-treated groups: ${ }^{* * *} P<0.001$. ${ }^{\mathrm{b}}$ Statistical difference between the group of embryos treated with $10 \mu \mathrm{M}$ UK 14304 and the embryos treated with the two lower doses of UK 14 304: ${ }^{*} P<0.05,{ }^{* *} P<0.01$. antagonize each other's signaling. However, the ability of a Gi protein-coupled receptor to decrease cAMP production in the cell is not automatic; it depends, for example, on the isoform of adenylyl cyclase present in the cell (for review, see Cooper 2003). Moreover, it has been shown that under certain circumstances $\alpha 2$-adrenoceptors can even stimulate cAMP production in some cell types, and the effect of $\alpha 2$-adrenoceptors on cAMP production appears to be dependent on agonist concentration (Duzic \& Lanier 1992, Pepperl \& Regan 1993, Eason \& Liggett 1995, Pohjanoksa et al. 1997). An interesting cross-talk between $\alpha 2$-adrenoceptors and $\beta 2$ adrenergic receptor has been shown in pregnant rat myometrium with different receptor interactions at midpregnancy and in late pregnancy. By themselves, $\alpha 2-$ adrenoceptor agonists did not significantly influence adenylyl cyclase activity in myometrial cells, but they were able to modulate the enzyme activity after $\beta 2$ adrenoceptor stimulation (Mhaouty et al. 1995, LimonBoulez et al. 2001). The possibility of cross-talk between $\alpha 2-$ and $\beta$-adrenoceptors has also been shown in brain cells (Atkinson \& Minneman 1992, Shivachar \& Eikenburg 1999). These results indicate that simultaneous activation of $\beta$ - and $\alpha 2$ - adrenergic receptors in the same cell need not necessarily have a contradictory effect on cAMP production; the signaling pathway employed by the receptor depends on the cell type and physiological status as well as on the intensity of receptor stimulation by a particular agonist.

To examine the effect of $\alpha 2 \mathrm{C}$-adrenoceptor activation on the development of mouse preimplantation embryos, we exposed the embryos to three doses of the $\alpha 2$ adrenergic agonist UK 14304 . We found that the percentage of embryos which reached higher developmental stages was significantly reduced after the exposure of the embryos to UK 14 304. Estimation of the mean embryo cell number revealed that the effect of UK 14304 was dose dependent and led to significantly lower numbers of cells in UK 14 304-treated embryos in comparison with control embryos. These results indicate that activation of $\alpha 2 \mathrm{C}$-adrenoceptor in mouse preimplantation embryos can inhibit cell proliferation, similarly as shown for $\beta$-adrenergic receptors (Čikoš et al. 2005). The influence of adrenergic receptors on fundamental cellular processes has been demonstrated in various mammalian cell types, particularly regulation of cell proliferation, migration, and apoptosis by activated $\beta$ - and $\alpha 2$ - adrenoceptors (Kennedy et al. 1983, Seuwen et al. 1990, Wang \& Limbird 1997, Slotkin et al. 2000, Cussac et al. 2002, Kim et al. 2002, Shizukuda \& Buttrick 2002, Pullar \& Isseroff 2003, Zhu et al. 2003). Cell responses to stimulation of adrenergic receptors are mediated via various signaling pathways. The $\beta$-adrenoceptors coupled predominantly to Gs proteins regulate the activity of metabolic enzymes, ion channels, or transcription factors. The $\alpha 2$-adrenoceptors coupled primarily to $\mathrm{Gi}$ proteins inhibit the 
activity of adenylyl cyclase and voltage-gated $\mathrm{Ca}^{2+}$ channels and activate receptor-operated $\mathrm{K}^{+}$channels (for review see, Watson \& Arkinstall 1994, Saunders \& Limbird 1999). Moreover, stimulation or inhibition of mitogen-activated protein kinases by activated adrenergic receptors has been shown in several cell types utilizing a variety of signaling pathways (Alblas et al. 1993, DeGraff et al. 1999, Schramm \& Limbird 1999, Lindquist et al. 2000, Hutchinson et al. 2002, Shizukuda \& Buttrick 2002, Pullar \& Isseroff 2003).

Natural ligands for adrenergic receptors, epinephrine and norepinephrine, have been detected in the oviductal fluid of some species. Concentrations of these catecholamines varied with the region of the oviduct and with the stage of the estrous cycle (Khatchadourian et al. 1987, Way et al. 2001). The possible sources of norepinephrine and epinephrine in the oviductal fluid could be nerves, blood circulation or graafian follicles (Helm et al. 1982, Fernandez-Pardal et al. 1986, Kannisto et al. 1986, Itoh et al. 2000, Kotwica et al. 2003). Moreover, it was speculated that catecholamines could be produced also by the early embryo itself (Burden \& Lawrence 1973, Sadykova et al. 1990). Epinephrine and norepinephrine present in oviductal fluid could influence the oviduct epithelium via adrenergic receptors which have been shown in oviduct epithelial cells of several species (Tolszczuk \& Pelletier 1988, Dickens et al. 1993, Einspanier et al. 1999). Increased fluid formation, effects on $\mathrm{Cl}^{-}$ion transport and electrical potential differences have been shown after treatment of rabbit oviductal cells with agonists of adrenergic receptors (Dickens et al. 1993, Dickens \& Leese 1994). Besides, the effects on the oviduct epithelium, adrenoceptor agonists can also influence the functioning of spermatozoa in the oviduct, including capacitation and acrosome reaction (Way \& Killian 2002, Adeoya-Osiguwa et al. 2006).

It is well known that circulating levels of epinephrine and norepinephrine are highly elevated during stress and trauma. Animal experiments have convincingly demonstrated that prenatal maternal stress can significantly affect the pregnancy outcome (for review see Mulder et al. 2002). Some results suggest that maternal stress can negatively impact on the embryo even at very early stages of its development. For instance, it has been shown that litter sizes of female hamsters stressed during early pregnancy were significantly smaller than those of controls, with fetal loss occurring between days 5 and 10 of pregnancy (Pratt \& Lisk 1989). In humans, it has been demonstrated that pregnancies characterized by increased maternal cortizol (commonly used stress marker) during the first three weeks after conception are more likely to result in spontaneous abortion. (Nepomnaschy et al. 2006).

Our results indicate that, besides $\beta$-adrenergic receptors, the $\alpha 2 \mathrm{C}$-adrenoceptor is also expressed in mouse oocytes and preimplantation embryos. We also found that ligands for the receptors are capable of affecting the preimplantation embryo development in vitro. These results suggest that epinephrine and norepinephrine could directly affect embryo development in the oviduct via adrenergic receptors and support the opinion that maternal stress can influence the embryo even in very early pregnancy.

\section{Acknowledgements}

This work was supported by Grant 2/6176/6 from the Slovak Academy of Sciences. The authors declare that there is no conflict of interest that would prejudice the impartiality of this scientific work.

\section{References}

Adeoya-Osiguwa SA, Gibbons R \& Fraser LR 2006 Identification of functional $\alpha 2$ - and $\beta$-adrenergic receptors in mammalian spermatozoa. Human Reproduction 21 1555-1563.

Alblas J, Van Corven EJ, Hordijk PL, Milligan G \& Moolenaar WH 1993 $\mathrm{G}_{\mathrm{i}}$ - mediated activation of the p2 $1^{\text {ras }}$-mitogen-activated protein kinase pathway by $\alpha_{2}$-adrenergic receptors expressed in fibroblasts. Journal of Biological Chemistry 268 22235-22238.

Altschul SF, Madden TL, Schäffer AA, Zhang J, Zhang Z, Miller W \& Lipman DJ 1997 Gapped BLAST and PSI-BLAST: a new generation of protein database search programs. Nucleic Acid Research 25 3389-3402.

Atkinson BN \& Minneman KP 1992 Preferential desensitization of $\beta$-versus $\alpha_{2}$-adrenergic receptors accelerates loss of response to norepinephrine in primary glial cultures. Molecular Pharmacology 41 688-694.

Burden HW \& Lawrence IE Jr 1973 Presence of biogenic amines in early rat development. American Journal of Anatomy 136 251-257.

Buznikov GA, Shmukler YB \& Lauder JM 1996 From oocyte to neuron: do neurotransmitters function in the same way throughout development? Cellular and Molecular Neurobiology 16 533-559.

Čikoš Š, Veselá J, Ilková G, Rehák P, Czikková S \& Koppel J 2005 Expression of beta adrenergic receptors in mouse oocytes and preimplantation embryos. Molecular Reproduction and Development 71 145-153.

Cooper DMF 2003 Regulation and organization of adenylyl cyclases and CAMP. Biochemical Journal 375 517-529.

Cussac D, Schaak S, Gales C, Flordellis Ch, Denis C \& Paris H 2002 $\alpha_{2 \mathrm{~B}}$-Adrenergic receptors activate MAPK and modulate proliferation of primary cultured proximal tubule cells. American Journal of Physiology. Renal Physiology 282 943-952.

Dickens CJ \& Leese HJ 1994 The regulation of rabbit oviduct fluid formation. Journal of Reproduction and Fertility 100 577-581.

Dickens CJ, Southgate J \& Leese HJ 1993 Use of primary cultures of rabbit oviduct epithelial cells to study the ionic basis of tubal fluid formation. Journal of Reproduction and Fertility 98 603-610.

Duzic E \& Lanier SM 1992 Factors determining the specificity of signal transduction by guanine nucleotide-binding protein-coupled receptors III. Coupling of alpha adrenergic receptor subtypes in a cell type-specific manner. Journal of Biological Chemistry 267 24045-24052.

Eason MG \& LiggettSB 1995 Identification of a Gs coupling domain in the amino terminus of the third intracellular loop of the $\alpha_{2 \mathrm{~A}}$-adrenergic receptor. Journal of Biological Chemistry $27024753-24760$.

Einspanier R, Gabler C, Kettler A \& Kloas W 1999 Characterization and localization of $B_{2}$-adrenergic receptors in the bovine oviduct: indication for progesterone-mediated expression. Endocrinology 140 2679-2684. 
Fernandez-Pardal J, Gimeno MF \& Gimeno AL 1986 Catecholamines in sow graafian follicles at proestrus and at diestrus. Biology of Reproduction 34 439-445.

DeGraff JL, Gagnon AW, Benovic JL \& Orsini MJ 1999 Role of arrestins in endocytosis and signaling of alpha2-adrenergic receptor subtypes. Journal of Biological Chemistry 274 11253-11259.

Helm G, Owman C, Rosengren E \& Sjoberg NO 1982 Regional and cyclic variations in catecholamine concentration of the human fallopian tube. Biology of Reproduction 26 553-558.

Herlenius E \& Lagercrantz H 2001 Neurotransmitters and neuromodulators during early human development. Early Human Development $6521-37$.

Higgins DG, Thompson JD \& Gibson TJ 1996 Using CLUSTAL for multiple sequence alignments. Methods in Enzymology 266 383-402.

Hutchinson DS, Bengtsson T, Evans BA \& Summers RJ 2002 Mouse $\beta_{3 a}$ -and $\beta_{3 b^{-}}$adrenoceptors expressed in Chinese hamster ovary cells display identical pharmacology but utilize distinct signalling pathways. British Journal of Pharmacology 135 1903-1914.

Itoh MT, Ishizuka B, Kuribayashi Y, Abe Y \& Sumi Y 2000 Noradrenaline concentrations in human preovulatory follicular fluid exceed those in peripheral plasma. Experimental and Clinical Endocrinology and Diabetes 108 506-509.

Kannisto P, Ekblad E, Helm G, Owman C, Sjoberg NO, Stjernquist M, Sundler F \& Walles B 1986 Existence and coexistence of peptides in nerves of the mammalian ovary and oviduct demonstrated by immunocytochemistry. Histochemistry 86 25-34.

Kennedy MF, Tutton PJ \& Barkla DH 1983 Adrenergic factors involved in the control of crypt cell proliferation in jejunum and descending colon of mouse. Clinical and Experimental Pharmacology and Physiology 10 577-586.

Khatchadourian C, Menezo Y, Gerard M \& Thibault C 1987 Catecholamines within the rabbit oviduct at fertilization time. Human Reproduction 2 1-5.

Kim J, Eckhart AD, Eguchi S \& Koch WJ 2002 Beta-adrenergic receptormediated DNA synthesis in cardiac fibroblasts is dependent on transactivation of the epidermal growth factor receptor and subsequent activation of extracellular signal-regulated kinases. Journal of Biological Chemistry 277 32116-32123.

Kobayashi K, Morita S, Sawada H, Mizuguchi T, Yamada K, Nagatsu J, Hata T, Watanabe Y, Fujita K \& Nagatsu T 1995 Targeted disruption of the tyrosine hydroxylase locus results in severe catecholamine depletion and perinatal lethality in mice. Journal of Biological Chemistry $27027235-27243$.

Kotwica G, Kurowicka B, Franczak A, Grzegorzewski W, Wrobel M, Mlynarczuk J \& Kotwica J 2003 The concentrations of catecholamines and oxytocin receptors in the oviduct and its contractile activity in cows during the estrous cycle. Theriogenology 15 953-964.

Lawits JA \& Biggers JD 1993 Culture of preimplantation embryos. In Guide to Techniques in Mouse Development. Methods in Enzymology, pp 153-164. Eds PM Wassarman \& ML DePhamphilis. San Diego: Academic Press.

Limon-Boulez I, Bouet-Alard R, Gettys TW, Lanier SM, Maltier JP \& Legrand C 2001 Partial agonist clonidine mediates alpha(2)-AR subtypes specific regulation of cAMP accumulation in adenylyl cyclase II transfected DDT1-MF2 cells. Molecular Pharmacology 59 331-338.

Lindquist JM, Fredriksson JM, Rehnmark S, Cannon B \& Nedergaard J 2000 Beta 3- and alpha1- adrenergic Erk1/2 activation is Src- but not Gi- mediated in Brown adipocytes. Journal of Biological Chemistry $27522670-22677$.

Liss B 2002 Improved quantitative real-time RT-PCR for expression profiling of individual cells. Nucleic Acids Research 30 e89.

Mhaouty S, Cohen-Tannoudji J, Bouet-Alard R, Limon-Boulez I, Maltier JP \& Legrand C 1995 Characteristics of the $\alpha_{2} / \beta_{2^{-}}$adrenergic receptor-coupled adenylyl cyclase system in rat myometrium during pregnancy. Journal of Biological Chemistry 270 11012-11016.
Mulder EHJ, Robles de Medina PG, Huizink AC, Van den Bergh BRH, Buitelaar JK \& Visser GHA 2002 Prenatal maternal stress: effects on pregnancy and the (unborn) child. Early Human Development 70 3-14.

Nepomnaschy PA, Welch KB, McConnell DS, Low BS, Strassmann BI \& England BG 2006 Cortisol levels and very early pregnancy loss in humans. PNAS 103 3938-3942.

Pendleton RG, Rasheed A, Roychowdhury R \& Hillman R 1998 A new role for catecholamines: ontogenesis. Trends in Pharmacological Sciences 19 248-251.

Pepperl DJ \& Regan JW 1993 Selective coupling of alpha 2-adrenergic receptor subtypes to cyclic AMP-dependent reporter gene expression in transiently transfected JEG-3 cells. Molecular Pharmacology 44 802-809.

Pohjanoksa k, Jansson ChC, Luomala K, Marjamäki A, Savola JM \& Scheinin M $1997 \alpha_{2}$-Adrenoceptor regulation of adenylyl cyclase in $\mathrm{CHO}$ cells: dependence on receptor density, receptor subtype and current activity of adenylyl cyclase. European Journal of Pharmacology 335 53-63.

Pratt NC \& Lisk RD 1989 Effects of social stress during early pregnancy on litter size and sex ratio in the golden hamster (Mesocricetus auratus). Journal of Reproduction and Fertility $\mathbf{8 7}$ 763-769.

Pullar CE \& Isseroff RR 2003 PP2A activation by beta2-adrenergic receptor agonists: novel regulatory mechanism of keratinocyte migration. Journal of Biological Chemistry 278 22555-22562.

Sadykova KA, Markova LN, Baikenova SD, Vsevolodov EB \& Buznikov GA 1990 Biogenic monoamines in ovum cells and preimplantation embryos of mice. Biulleten' Eksperimental' noi Biologii i Meditsiny 109 577-578.

Saunders C \& Limbird LE 1999 Localization and trafficking of $\alpha_{2^{-}}$ adrenergic receptor subtypes in cells and tissues. Pharmacology and Therapeutics 84 193-205.

Schramm NL \& Limbird LE 1999 Stimulation of mitogen-activated protein kinase by G protein - coupled alpha(2)-qdrenergic receptors does not require agonist-elicited endocytosis. Journal of Biological Chemistry 274 24935-24940.

Seuwen K, Magnaldo I, Kobilka BK, Caron MG, Regan JW, Lefkowitz RJ \& Pouyssegur J 1990 Alpha 2-adrenergic agonists stimulate DNA synthesis in Chinese hamster lung fibroblasts transfected with a human alpha 2-adrenergic receptor gene. Cellular Regulation 1 445-451.

Shivachar AC \& Eikenburg DC 1999 Differential effects of epinephrine and norepinephrine on cAMP response and $\mathrm{G}_{\mathrm{i} 3} \alpha$ protein expression in cultured sympathetic neurons. Journal of Pharmacology and Experimental Therapeutics 291 258-264.

Shizukuda Y \& Buttrick PM 2002 Subtype specific roles of beta-adrenergic receptors in apoptosis of adult rat ventricular myocytes. Journal of Molecular and Cellular Cardiology 34 823-831.

Slotkin TA, Yhang J, Dancel R, Garcia SJ, Willis C \& Seidler FJ 2000 Beta-adrenoceptor signaling and its control of cell replication in MDA-MB-231 human breast cancer cells. Breast Cancer Research and Treatment 60 153-166.

Temeles GL, Ram PT, Rothstein JL \& Schultz RM 1994 Expression patterns of novel genes during mouse preimplantation embryogenesis. Molecular Reproduction and Development 37 121-129.

Thomas SA, Matsumoto AM \& Palmiter RD 1995 Noradrenaline is essential for mouse fetal development. Nature 374 643-646.

Tolszczuk M \& Pelletier G 1988 Autoradiographic localization of betaadrenergic receptors in rat oviduct. Molecular and Cellular Endocrinology 60 95-99.

Wang RX \& Limbird LE 1997 Distribution of mRNA encoding three $\alpha_{2}$-adrenergic receptor subtypes in the developing mouse embryo suggests a role for the $\alpha_{2 \mathrm{~A}}$ subtype in apoptosis. Molecular Pharmacology 52 1071-1080. 
Watson S \& Arkinstall S 1994 Adrenaline and noradrenaline, The G-protein Linked Receptor Factsbook, London: Academic Press Limited, pp 32-55.

Way AL \& Killian GJ 2002 Capacitation and induction of the acrosome reaction in bull spermatozoa with norepinephrine. Journal of Andrology 23 352-357.

Way AL, Barbato GF \& Killian GJ 2001 Identification of norepinephrine in bovine oviductal fluid by high performance liquid chromatography. Life Sciences 70 567-576.

Weiss ER, Maness P \& Lauder JM 1998 Why do neurotransmitters act like growth factors? Perspectives on Developmental Neurobiology $\mathbf{5}$ 323-335.
Zhou QJ, Quaife CJ \& Palmiter RD 1995 Targeted disruption of the tyrosine hydroxylase gene reveals that catecholamines are required for mouse fetal development. Nature 374 640-646.

Zhu XH, He QL \& Lin ZH 2003 Effects of catecholamines on human preadipocyte proliferation and differentiation. Zhonghua Zheng Xing Wai Ke Za Zhi 19 282-284.

Received 4 January 2007

First decision 6 February 2007

Accepted 22 February 2007 